4. Rosenthal VD, Guzman S, Migone O, Crnich CJ. The attributable cost length of hospital stay, and mortality of central line-associated bloodstream infection in intensive care department in Argentina: a prospective, matched analysis. Am J Infect Control 2003;34: $475-480$.

5. Higera F, Rangel-Frausto MS, Rosenthal VD, et al. Attributable cost and length of stay for patients with central venous catheter venous catheter-associated bloodstream infection in Mexico City intensive care units: a prospective, matched analysis. Infect Control Hospital Hosp Epidemiol 2007;28:31-35.

6. Sulis CA, Walkey AJ, Abadi Y, Campbell Reardon C, Joyce-Brady M. Outcomes of a ventilator-associated pneumonia bundle on rates of ventilator-associated pneumonia and other health care-associated infections in a long-term acute care hospital setting. Am J Infect Control 2014;42:536-538.

\section{Psychodidae (Drain Fly) Infestation in an Operating Room}

To the Editor-Insect infestation is a problem in many hospitals, mostly related to food storage, drainage systems, or open access to the outside environment. However, its occurrence in operating rooms is a rare occurrence. We report a case of drain fly infestation, the associated technical investigation, and pest control measures and discuss the potential medical implications and preventive measures.

The infection control team was urgently alerted because the staff of an outpatient surgical center spotted insects, later identified as drain flies (Psychoda grisescens), in one of the operating rooms.

Because of the large quantity of insects the operating room was closed and sealed.

During the on-site inspection drain flies were seen in one of the operating rooms (room 3) in large numbers adjacent to an air vent of the ventilation system equipped with a HEPA-filter and in small numbers in a neighboring operating room (room 4) close to an electric outlet.

The revision openings of the ventilation ducts were opened but no insects could be detected. However, the ducts appeared dusty and were thoroughly cleaned.

Because a fly was spotted on a ceiling panel the ceiling was opened and in the ceiling space several drain pipes and electric wiring pipes were visible in close proximity without adequate fitting. Finally the electric outlets were removed and several hundred dead and living drain flies as well as larvae were spotted. The wiring duct could be followed into the cellar, where recent flooding had caused water damage and standing water for several days, immersing drain pipes connected to the ducts that were unintentionally interconnected to the electric wiring ducts. There were water marks indicating flood water entering the duct system. Currently this is thought to be the route of entry.
An approved insecticide was sprayed into the duct system by a licensed exterminator. All openly stored material in the operating rooms was removed, and sinks and their siphons in the rooms adjacent to the operating rooms were thoroughly cleaned in order to destroy potential food sources and nesting grounds.

Several technical measures were implemented, including closure of connecting duct systems, installation of flood-safety valves in the draining pipe system, and special isolation of the electric wiring as required by the applicable technical norms and building codes.

After clearance by the exterminator the operating rooms were cleaned and disinfected according to local standard operating procedures and reopened for service without further incidence.

Moth flies, also known as drain flies, are small true flies (Diptera) with short, hairy bodies and wings, giving them a "furry" moth-like appearance. Among Diptera this family of flies is probably also the most diverse biologically and taxonomically. ${ }^{1}$ Our species were identified as Psychoda grisescens. The adult insects have long antennae and the wings are leaf-shaped, showing little more than a series of parallel veins without cross veins. Adult drain flies typically live in damp habitats and show a nocturnal life pattern. There are 6 subfamilies, whose relationships are not well understood. The larvae of the subfamilies Psychodinae, Sycoracinae, and Horaiellinae are aquatic, semiaquatic, or marginal in habit. Their larvae play major roles in the breakdown of mammalian dung, ${ }^{2}$ in nutrient recycling in freshwater habitats, and as saprophages on fallen leaves and animal remains. They also often abound in latrines, septic tank outflows, and organically polluted mudflats, streams, etc., ${ }^{3}$ and in sewage disposal systems, especially trickling filter beds. ${ }^{4}$ Some species are commonly found in bathrooms, where they find food sources such as hair clogs in drains and biofilm in siphons.

The subfamily Phlebotominae (called sand flies outside the United States) includes many blood-feeding species that are inhabitants of more arid regions and a very important group medically, transmitting various tropical diseases like kala-azar leishmaniasis and described as vectors for bartonellosis and bunyaviridae. ${ }^{5-7}$

The European species Sycorax silacea has been shown to transmit microfilarian worms.

However, none of those complications have been reported with Psychoda grisescens, which are under normal circumstances more of a nuisance in bathrooms and kitchens. Because they primarily live in or near sewage water and were most likely introduced by flood water into the surgery center, carriage of typical fecal bacteria and the risk of contact infection had to be considered in an operating room, making the immediate closure necessary, given the large number of observed insects.

Rapid communication between technical staff, the infection control team, and an exterminator was essential for the quick resolution of the situation, and no patient was harmed.

With more and more construction projects using hanging ceilings and connected duct systems, a detailed wiring and pipe plan should be mandatory for new buildings in the medical 
field in order to prevent destructive investigations by opening walls and ceilings on a large scale in the case of problems like ours.

Drain pipes and electric wiring should be completely separated and openings in flood-prone areas like cellars sufficiently sealed.

\section{ACKNOW LEDGMENTS}

Financial support. None reported.

Potential conflicts of interest. S.S-S., T.H., and E.T. report that they are co-owners of the BZH. K.D. reports no conflicts of interest relevant to this article.

\section{Sebastian Schulz-Stübner, $\mathrm{MD}, \mathrm{PhD}^{1}$ Kathrin Danner, RN; ${ }^{1}$ Thomas Hauer, MD; ${ }^{1}$ Ernst Tabori, $\mathrm{MD}^{1}$}

Affiliations: 1. German Consulting Center for Infection Control and Prevention (Deutsches Beratungszentrum für Hygiene, BZH), Freiburg im Breisgau, Germany.

Address correspondence to Sebastian Schulz-Stübner, $\mathrm{MD}, \mathrm{PhD}$, Deutsches Beratungszentrum für Hygiene (BZH), Schnewlinstr. 10, 79098 Freiburg im Breisgau, Germany (Schulz-stuebner@bzh-freiburg.de).

Infect Control Hosp Epidemiol 2015;36(3):366-367

(C) 2014 by The Society for Healthcare Epidemiology of America. All rights reserved. 0899-823X/2015/3603-0023. DOI: 10.1017/ice.2014.43

\section{REFERENCES}

1. Quate LW, Vockeroth JR. Psychodidae. In: McAlpine JF, Peterson BV, Shewell GE, Teskey HJ, Vockeroth JR, Wood DM, eds. Manual of Nearctic Diptera. Vol. 1. Ottawa: Research Branch, Agriculture Canada, Monograph 27; 1981:293-300.

2. Laurence BR. The larval inhabitants of cow pats. J Anim Ecol 1954;23:234-260.

3. Lloyd L. Observations on sewage flies: their seasonal incidence and abundance. J Institute Sewage Purification 1937: 150-168.

4. Lloyd L, Crisp G. The community of insects in a patch of woodland mud. Trans R Entomol Soc Lond 1954;105:269-313.

5. Ergunay K, Erisoz Kasap O, Kocak Tufan Z, Turan MH, Ozkul A, Alten B. Molecular evidence indicates that Phlebotomus major sensu lato (Diptera: Psychodidae) is the vector species of the recently-identified sandfly fever Sicilian virus variant: sandfly fever turkey virus. Vector Borne Zoonotic Dis 2012;12: 690-698.

6. Ergunay K, Ismayilova V, Colpak IA, Kansu T, Us D. A case of central nervous system infection due to a novel Sandfly Fever Virus (SFV) variant: Sandfly Fever Turkey Virus (SFTV). J Clin Virol 2012;54:79-82.

7. Casaril AE, Monaco NZ, de Oliveira EF, et al. Spatiotemporal analysis of sandfly fauna (Diptera: Psychodidae) in an endemic area of visceral leishmaniasis at Pantanal, central South America. Parasit Vectors 2014;7:364. 